DOI: 10.21802/artm.2020.1.13.201.

УДК $615.83+616.858$

\title{
ОСОБЛИВОСТІ ЗАСТОСУВАННЯ ЗАСОБІВ ФІЗИЧНОЇ ТЕРАПІЇ ПРИ ХВОРОБІ ПАРКІНСОНА
}

\author{
В.Г. Тудоси
}

Івано-Франківський наџіональний медичний університет, кафедра фізичної реабілітації, ерготерапї̈ з курсом фізичного виховання, м. Івано-Франківськ, Украйна,

ORCID ID: 0000-0003-2584-3330, e-mail: tudosyv@gmail.com

Резюме. Хвороба Паркінсона була відкрита і описана вже більше ніж 250 років тому Дж. Паркінсоном. Вона $\epsilon$ найрозповсюдженішим хронічним захворюванням, що уражає людей переважно похилого віку (старше 60 років). В основі захворювання лежить прогресуюче руйнування нейронів, які виробляють нейромедіатор дофамін у чорній субстанції. 3 часом недостатність вироблення дофаміну веде до виникнення моторних і немоторних проявів захворювання. Ознаки хвороби Паркінсона - ригідність рухів, тремор, гіпокінезія, постуральні порушення, вегетативні, когнітивні і психологічні порушення, проблеми з мовою і ковтанням. У 1976 році Хеном і Яром було запропоновано 5 стадій захворювання, перехід з однієї стадії в іншу відзначається 3-ма типами прогресування. Більшість авторів відмічають доцільність застосування різних реабілітаційних заходів і медикаментозного лікування. Завдання фізичної терапії - попередження або зменшення темпів прогресування симптоматики і пристосування хворих до вже наявних рухових порушень. Позитивно на організм впливає масаж він сприяє нормалізації функцій ЦНС і відновлює м'язову рухливість. Ціль ерготерапії полягає в тому, щоб забезпечити незалежність пацієнта в повсякденній діяльності від сторонньої допомоги, облаштувати його оточення зручними та безпечними речами. За допомогою методу біоуправління у хворого формується рухова навичка самостійного контролю положення центра тиску, яка в подальшому допомагає рухатися без втрати рівноваги. Доцільним $є$ впровадження в комплекс фізичної терапії приформованих фізичних факторів - гідротерапія (прісні, перлинові, хлориднонатрієві, йодобромні, сірчані ванни), електросудомна терапія.

Ключові слова: хвороба Паркінсона, фізична терапія, ерготерапія, біоуправління.

Вступ. Хвороба Паркінсона - друге за поширеністю нейродегенеративне захворювання після хвороби Альцгеймера. За даними центру громадського здоров'я МОЗ України, на сьогодні хвороба Паркінсона набирає великі темпи щодо поширення у світі й в Україні зокрема. Станом на 11 квітня 2019 року у світі налічується 4 млн. пацієнтів із хворобою Паркінсона, а в Україні зареєстровано понад 23000 людей; це 61,4 на 100000 населення. Кожного року про цей діагноз дізнаються понад 2500 українців $[1,2,3]$.

Отже, хвороба Паркінсона, або тремтливий параліч, - повільно прогресуюче хронічне неврологічне захворювання, притаманне особам літнього віку. Відноситься до дегенеративних захворювань екстрапірамідної моторної системи. Викликано прогресуючим руйнуванням нейронів, які виробляють нейромедіатор дофамін - насамперед у чорній субстанції, а також і в інших відділах центральної нервової системи. Недостатнє вироблення дофаміну веде до активного впливу базальних гангліїв на кору головного мозку [4].

Першим описав це захворювання в 1817 році Дж. Паркінсон у своїй монографіï «An Essay on the Shaking Palsy», у якій було перераховано симптоми, як розвивається захворювання і які контингенти найчастіше хворіють. А першим лікувати ХП почав французький невролог Шарко, який, зрештою, і назвав $\dddot{11}$ хворобою Паркінсона.

Дотепер конкретних етіологічних факторів виникнення хвороби Паркінсона немає. Але велике значення мають вік, стать (чоловіки хворіють частіше, ніж жінки), зовнішнє середовище, спадковість.

Хворобу можна розпізнати за такими ознаками: ригідність рухів, тремор, гіпокінезія, поступальні порушення, когнітивні порушення.

Для контролю симптомів і адаптації до виконання простих, повсякденних завдань знадобиться довготривале лікування, як медикаментозне, так i підтримувальна терапія. До підтримувальної терапії входять: дієтотерапія, ЛФК, масаж, фізіотерапія.

Великі труднощі в людей з хворобою Паркінсона пов'язані з рухом, а саме з контролем положення тіла, початком руху, зупинкою, зміною напрямку руху, координацією. Для таких людей характерна ходьба - дрібні, повільні кроки. Тому важливо в процесі реабілітації формувати нормальний стереотип руху, покращити координацію, унормувати м'язову напругу і підвищений тонус м'язів.

Мета дослідження: визначити ефективність застосування фізичної терапії в комплексній реабілітації пацієнтів з хворобою Паркінсона.

Методи дослідження: аналіз та узагальнення вітчизняної та зарубіжної літератури.

Результати дослідження. Хвороба Паркінсона - це повільно прогресуюче нейродегенеративне захворювання центральної нервової системи (ЦНС), яке найчастіше проявляється в людей старше 60 років і має такі симптоми: гіпокінезія, тремор у спокої, ригідність м'язів, поступальні, когнітивні, вегетативні та інші розлади. За міжнародною класифікацією 
хвороб (МКХ-10), ХП відноситься до класу VI, рубрики G-20-G26.

Ознаки хвороби Паркінсона можуть проявлятися як початки інших дегенеративних захворювань НС (хвороби Гентінгтона, Альцгеймера, Піка, Фара, Вільсона-Коновалова, Сегави). За деякими даними відомо, що ХП має схильність до спадковості. $15 \%$ хворих людей мали сімейний анамнез. Але гени, які відповідають за це захворювання, так і не були виявлені.

Хвороба Паркінсона може виникати в результаті гострих чи хронічних інфекцій НC, атеросклерозу судин головного мозку, інсульту, пухлин, інтоксикації медикаментами $[1,2]$.

Каменецький у своїй праці відзначив, що неврологи виявили приблизно однаковий набір рухових порушень як у чоловіків, так і в жінок, а от супутні проблеми в кожної статі були свої. Чоловіки частіше скаржаться на запаморочення, падіння артеріального тиску, порушення сечопуску, закрепи, а жінки - на біль і депресію [1].

Ознаки ХП: тремор, ригідність рухів, гіпокінезія, поступальні порушення, вегетативні, когнітивні і психологічні порушення, проблеми 3 мовою і ковтанням [3].

Тремор - найбільш видимий симптом, він посилюється при хвилюванні і зникає або послаблюється при довільних рухах i сні. Зазвичай тремор розвивається в дистальних відділах верхньої кінцівки на одній стороні тіла, з часом переходить і на іншу кінцівку, потім на ноги, виникає найчастіше в спокої, але можливі й інші типи. Частота тремору 4-6 Гц/с. Інколи відмічається тремтіння голови, по типу «тактак» або «ні-ні», повік, нижньої щелепи і навіть язика, дуже рідко всього тіла [3, 4].

Гіпокінезія або брадикінезія - одні з причин рухових порушень, коли рухи стають сповільнені, незграбні, скуті, зменшується їх об’єм і швидкість. Хворі можуть годинами зберігати нерухомий стан. Гіпокінези проявляються у всіх хворих. Для них характерна «лялькова хода» - дрібні кроки, ступні при цьому розташовані паралельно один до одного, застиглий погляд, рідке моргання, маскоподібне обличчя, посмішка або плач виникають з запізненням так само і зникають, мова монотонна, під час письма об'єм рухів зменшується і букви стають дрібними [1].

Однією з ознак гіпокінезії є відсутність синкінезій (співдружніх рухів). Зазвичай при ходьбі руки допомагають розігнатися і підтримувати темп ходи, а при хворобі руки притиснуті до тулуба. Хворий може виконати тільки один цілеспрямований рух, автоматично [3].

Ригідність м'язів виникає через підвищення тонусу м'язів, рухи стають скутими, відчувається опір при спробі зробити довільний рух. Через це формується характерна поза, хворий сутулиться, голова нахилена вперед, лікті напівзігнуті, притиснуті до тіла, ноги також напівзігнуті в колінних і кульшових суглобах. Наявний «симптом зубчастого колеса», який погіршується при повторних рухах; наприклад, при пасивному згинанні-розгинанні голови чи передпліччя відчуваються перервні напруження м'язів [4].
При хворобі Паркінсона спостерігається феномен Вестфаля - після активного руху кінцівка не відразу повертається у вихідне положення, а на деякий час затримується у вибраному положенні [3].

Постуральні порушення - з'являються переважно на пізніх стадіях. При спробі хворого різко почати рух у заданому напрямку чи зупинитися тулуб випереджує ноги, у результаті чого виникає постуральна нестабільність, центр ваги тіла зміщається вперед - і виникає ризик падіння. Змінюється тип ходи кроки короткі, шаркаючи, ускладнений початок i завершення руху [3].

Вегетативні порушення - виникають часто i несуть ускладнювальний характер. Серед вегетативних порушень - порушення обміну речовин (кахексія або ожиріння), гіперсалівація, пітливість, закрепи, урологічні розлади, порушення сну [5].

Когнітивні порушення - порушення пам'яті, обробки інформації та іiі запам'ятовування, сповільнене мислення, хворий не може швидко переключити свою увагу, коли виконує декілька завдань одночасно. На думку деяких дослідників, заучування певної інформації поліпшує пам'ять. Близько 20 \% людей 3 важкими когнітивними порушеннями мають ознаки деменції [4]. У хворих часто виникають психологічні порушення, такі як: депресія, тривожні стани, паніка, апатія [4].

Симптоми порушення мови i ковтання 3'являються на більш пізніх стадіях хвороби, внаслідок чого знижується якість життя пацієнтів і виникає потреба в догляді. Мова стає повільною, монотонною, без емоційного забарвлення, голос - слабкий і глухий [6].

У 1976 році Хеном і Яром було запропоновано 5 стадій хвороби Паркінсона, які добре відображали ступінь захворювання. 1 - симптоми проявляються на одній з кінцівок; 2 - двосторонні прояви без постуральних порушень; 3 - двосторонні прояви, постуральна нестійкість, хворий здатен до самообслуговування; 4 - значна втрата рухової активності, але може стояти і пересуватись без підтримки; 5 - повна втрата самостійної рухової активності. Тяжка інвалідизація $[1,2]$.

Н. В. Федорова виділила 3 типи прогресування ХП в залежності від зміни стадії хвороби: швидкий, якщо стадії змінюються за 2 роки або менше; помірний, якщо стадії змінюються протягом 3-5 років; повільний, якщо стадії змінюються протягом 5 років або більше [1].

Американська асоціація людей 3 хворобою Паркінсона запропонувала деякі вказівки.

Під час ходьби ноги повинні бути розставлені на рівні 25 см, ніякому випадку не схрещувати їх, навіть при стоянні. Для запобігання човганню і спотиканню якнайшвидше піднімати ступні при русі. Завжди дивитися вперед, а не під ноги, робити ширші кроки, махати руками, заздалегідь планувати зміну курсу, поворот чи зупинку. Якщо швидкість занадто велика і пацієнт це усвідомлює, то потрібно зупинитися і надалі починати рух з високо піднятими колінами, широким кроком. Рекомендують мовчати під 
час ходьби, щоб не відволікати і не збивати з установленого курсу і правильного виконання ходи.

Під час тренування ходьби можна рахувати в такт крокам чи під музику, для зберігання і контролю правильної постави - ходити перед дзеркалом, переступати через невеликі перешкоди, тримати щось в руках (тягарці чи скручену газету). Обов'язково носити тверде і зручне взуття для кращої стійкості і зменшення скутості.

Уникати тривалого сидіння і лежання, можна переробити одяг з гудзиків на блискавки чи липучки для зручності і швидкого одягання.

Для боротьби з дизартрією і гіперсалівацією рекомендують виконувати логопедичну гімнастику, вправи $з$ ритмічним диханням і отримати консультацію логопеда [1].

Обов'язково проводити заняття реабілітацією для сповільнення прогресування хвороби. Американська асоціація назвала головну мету реабілітаційного лікування - релаксація м'язів і суглобів, зменшення атрофії м'язів. За допомогою розтягування вкорочених м'язів можна сприяти збільшенню амплітуди рухів у суглобах, покращити координацію і поставу, збільшити крок під час ходи $[2,6]$.

Завданням фізичних терапевтів є знаходження оптимальної стратегії виконання тих рухів, які $є$ утрудненні, тренувати самостійність людей для попередження швидкої інвалідизації. Особливим моментом $є$ те, що програма реабілітації для кожного пацієнта повинна бути індивідуальною і розв'язувати наявні проблеми конкретної особи [6].

Потрібно пам'ятати, що рухові якості великою мірою залежать від оточення, а особливо вдома, чи $є$ достатньо місця для пересування, чи не заважають килими на підлозі, наскільки зручне ліжко і якої воно висоти. Знаючи і оцінивши ці всі деталі, можна надати певні рекомендації родичам пацієнта [2].

Лікування хвороби Паркінсона ні в якому випадку не можна обмежувати медикаментозним лікуванням, важливою складовою $є$ фізична терапія 3 комплексним застосуванням різних засобів. Регулярна реабілітація може сповільнювати прогресування симптомів захворювання. Завдання фізичної терапії попередження або зменшення темпів прогресування симптоматики і пристосування хворих до вже наявних рухових порушень $[1,7]$.

Більшість авторів відмічають доцільність комплексного застосування різних реабілітаційних заходів і медикаментозного лікування в боротьбі 3 другорядними симптомокомплексами, через вимушено акінетичний стиль життя, м'язові контрактури, різні деформуючі артрози чи больові синдроми [6].

Враховуючи всю симптоматику захворювання можна сказати, що лікування є комплексним i довготривалим 3 урахуванням стадії захворювання супутніх ускладнень, стану хворого, якості медикаментозного лікування $[1,2]$.

У своїй статті Митько Е. В. [6] наголошує на потребі регулярних занять лікувальною фізичною культурою, дозованою ходьбою, плаванням. I вказує на основні завдання, які повинні бути дотримані в ході проведення реабілітаційного процесу: підтримка загальної рухової активності, збільшення сили і рух- ливості м'язів, зменшення тонусу м'язів, збільшення рухливості суглобів, збільшення рівноваги. Заняття ЛГ покращують стан дихання, чим і впливають на голос і мову. Вправи повинні виконуватися для всіх м'язових груп і у всіх суглобах, збільшуючи їх амплітуду і рухливість. На кожному занятті потрібно тренувати певну групу м'язів, більша частина вправ спрямовується на тренування тих м'язових груп i рухів, які допоможуть перебороти наявні рухові порушення, спричинені хворобою. Пацієнти краще виконують вправи, якщо є музичний супровід, метроном або будь-яка ритмічна мелодія, навіть просто рахуючи вголос.

Ольга Агафонава [1] стверджує, що прекрасні результати дає виконання в комплексі терапії масажу кожного дня або через день. Він позитивно впливає на нормалізацію функцій ЦНС і відновлює м'язову рухливість. Кадиков А. С. у свою чергу наголошує на виключенні 3 масажу жорстких технік і надання переваги комбінованим прийомам мануального класичного масажу і точкового. Митько Е. В. рекомендує призначати масаж пацієнтам 3 хворобою Паркінсона курсами 15-20 процедур кожного дня, тривалість 1020 хвилин. Спочатку впливати на шийно-комірцеву зону, спину (паравертебральні зони), сідничні м'язи, нижні кінцівки, а потім - на верхні кінцівки. Виключити прийоми - рублення, поплескування і биття. В основі масажу повинні бути прийоми розминання 3 прогладжуванням і потрушуванням м'язів.

Кадиков А. С. [2] говорить про доцільність впровадження в комплекс фізичної терапії приформованих фізичних факторів (фізіотерапія). Їх застосування направлене на сповільнення прогресування хвороби і покращення якості життя шляхом підвищення функціональних можливостей хворих. Методи фізіотерапії направленні на попередження контрактур, зниження ригідності й тремору, стимулювання рухової активності, підвищення фізичної і емоційної активності. За думкою деяких авторів (Гурнеля А. М, Багель Г. Е) при лікуванні хвороби Паркінсона ефективним засобом є гідротерапія, а саме - прісні, перлинові, хлориднонатрієві, йодобромні, сірчані ванни. Температура води повинна бути $37-38^{\circ} \mathrm{C}$, тривалість процедури - 15-20 хвилин, курс - 15-20 процедур. Митько Е. В. пропонує застосовувати електросудомну терапію, вона викликає значне підвищення концентрації дофаміну в синаптичній щілині після судом, виражає швидко наступаючу сильну антипаркінсонічну дію, зменшує акінезії, скутість, ригідність й інші симптоми хвороби Паркінсона. Але через труднощі застосування електросудомної терапії цей метод використовується лиш в ургентних випадках: наприклад, акінетичний криз, суїцидальна депресія.

Кадиков А. С. [2] у своїй праці стверджує, що в комплекс фізичної терапії повинно входити широке коло методів, крім традиційних, - лікувальна гімнастика, фізіотерапія, масаж, новий метод - біоуправління по статокінезіограмі. Суть цього методу базується на принципі біологічного зворотного зв'язку, і в якості сигналу зворотного зв'язку виступає траєкторія переміщення проекції загального центру тиску на горизонтальну поверхню. Уся інформація у вигляді візуального сигналу відображається на моніторі, там 
моделюється ігрова ситуація, за умовами якої хворий повинен зміщувати центр тиску по напрямку до границі опори і назад в центр по заданій послідовності. Наявність візуального сигналу уточнює ступінь виконання рухового завдання i допомагає коригувати його. Таким чином, у хворого формується руховий навик самостійного контролю положення центра тиску, який у подальшому допомагає рухатися без втрати рівноваги. Цей метод підходить при початковій і середній стадіях Паркінсонізму, для пізніх стадій він не є досить ефективним.

Пилле Таба [3] наголошує на впровадженні в комплекс фізичної терапії - ерготарапії. Вона направлена на відновлення тих функцій організму, які допоможуть справлятися 3 повсякденною побутовою діяльністю. Першочергова увага надається функціонуванню верхніх кінцівок. Ціль полягає в тому, щоб забезпечити незалежність пацієнта в повсякденній діяльності від сторонньої допомоги, облаштувати його оточення зручними і безпечними речами, де все перебуває «під рукою». Так людина психологічно буде почувати себе краще, бо вона $є$ незалежною від сторонньої допомоги.

Хвороба Паркінсона значно обмежує такі побутові речі як одягання, прийом ванни, харчування, користування туалетом, похід в магазин, активний відпочинок, але за допомогою допоміжних засобів у спальні, туалеті, на кухні, на сходах пацієнт може стати менш залежний і навчитися самостійно справлятися з повсякденною діяльністю [3].

При лікуванні використовують метод як індивідуальної, так і групової терапії. Творчі види діяльності забезпечують покращення емоційного фону, дають можливість виразити себе у мистецтві, а малюючи чи в'яжучи покращується стан дрібної моторики. Цим також можна зняти стрес і дати можливість пацієнту створити щось своїми руками $[2,3]$.

\section{Висновки:}

1. Хвороба Паркінсона на сьогоднішній день $\epsilon$ розповсюдженим захворюванням $\mathrm{i}$, на превеликий жаль, кількість хворих постійно зростає.

2. Не встановлені етіологічні фактори виникнення хвороби Паркінсона.

3. Хвороба Паркінсона є хронічним захворюванням, але всі наявні методи лікування спрямовані на полегшення іiі симптомів (симптоматичне лікування) та покращення якості життя.

4. Основним фактором реабілітації хворих на хворобу Паркінсона $\epsilon$ комплексне застосування медикаментозного лікування і засобів фізичної терапії, а саме - лікувальної гімнастики, масажу, фізіотерапії, ерготерапії, біоуправління.

\section{References:}

1. Ahafonova OY, Bilianskyi OY. Osoblyvosti fizychnoi reabilitatsii pry khvorobi. Sportyvna nauka Ukrainy. 2014; May, 20, 3(61):7-11.

2. Kadikov AS, Chernykova NV, Shakhporonova LA. Reabilitatsiya nevrolohycheskykh bolnikih. MEDpress-ynform. Moskva. 2014; 3:171-202.

3. Taba P, Asser T, Krykmann Yu, Paiu T, Kanaryk Э, Eesti Haigekassa. Bolezn Parkynsona. 2007. P.12-49.
4. Shestopalova LF, Kozhevnykov VA. Osoblyvosti porushen kohnityvnykh funktsii ta osoblyvosti pry khvorobi Parkinsona. Ukr. visnyk psykhonevrolohii. 2011; 19(3):24-27.

5. Trufanov EA, Sukhoverskaia ON. Klynycheskye sootnoshenyia mezhdu nalychyem vehetatyvnykh rasstroistv y tiazhestiu zabolevanyia $\mathrm{u}$ bolnykh boleniu Parkynsona. Klynycheskaia anatomyia y operatyvnaia khyrurhyia. 2011; 10(2):57-61.

6. Mytko EV, Avramenko ON, Duhyna LV. Fizychna reabilitatsiia pry parkinsonizmi Slobozhanskyi naukovo-sportyvnyi visnyk. 2013; 5(38):165-169.

7. Voronyn DM, Mukhyn AN, Zvyriaka VN. Problemy prepodavanyia dystsyplyny «Fyzycheskaia reabylytatsyia pry zabolevanyiakh nervnoi systemy». Slobozhanskyi naukovo-sportyvnyi visnyk: [nauk.-teor. zhurn.]. Kharkiv: KhDAFK. 2011; 2:166-169.

8. Dobrokhotova TA, Zasoryna MA. Parkynsonyzm. Neiropsykhyatryia. Moskva. BYNOM. 2006. P.223226.

\section{УДК 615.83+616.858 \\ ОСОБЕННОСТИ ПРИМЕНЕНИЯ СРЕДСТВ ФИЗИЧЕСКОЙ ТЕРАПИИ ПРИ БОЛЕЗНИ ПАРКИНСОНА}

\section{В.Г. Тудоси}

\section{Ивано-Франковский нащиональный медицинский университет, кафедра физической реабилитации, эрготерапии с курсом физического воспитания, 2. Ивано-Франковск, Украина, ORCID ID: 0000-0003-2584-3330, e-mail:tudosyv@gmail.com}

Резюме. Болезнь Паркинсона была открыта и описана уже более 250 лет назад Дж. Паркинсоном. Она является распространенным хроническим заболеванием, которое поражает людей преимущественно пожилого возраста (старше 60 лет). В основе заболевания лежит прогрессирующее разрушение нейронов, которые производят нейромедиатор дофамин в черной субстанции. Со временем недостаточность выработки дофамина ведет к возникновению моторных и немоторных проявлений заболевания. Признаки болезни Паркинсона: ригидность движений, тремор, гипокинезия, постуральные нарушения, вегетативные, когнитивные и психологические нарушения, проблемы с речью и глотанием. В 1976 году Хеном и Яром было предложено 5 стадий заболевания, переход из одной стадии в другую отмечается 3-мя типами прогрессирования. Большинство авторов отмечают целесообразность применения различных реабилитационных мероприятий и медикаментозного лечения. Задача физической терапии - предупреждение или уменьшение темпов прогрессирования симптоматики и приспособления больных к уже имеющимся двигательным нарушениям. Положительно на организм влияет массаж - он способствует нормализации функций ЦНС и восстанавливает мышечную подвижность. Цель эрготерапии заключается в том, 
чтобы обеспечить независимость пациента в повседневной деятельности от посторонней помощи, обустроить его окружения удобными и безопасными вещами. С помощью метода биоуправления у больного формируется двигательный навык самостоятельного контроля положения центра давления, который в дальнейшем помогает двигаться без потери равновесия. Целесообразно внедрение в комплекс физической терапии физиотерапии - гидротерапии (пресные, жемчужные, хлориднонатриевые, йодобромные, серные ванны), электросудорожной терапии.

Ключевые слова: болезнь Паркинсона, физическая терапия, эрготерапия, биоуправления.

\section{UDC 615.83+616.858 \\ SPECIFICS OF APPLYING PHYSICAL THERAPY TO TREATMENT OF PARKINSON DISEASE}

V.H. Tudosy

Ivano-Frankivsk National Medical University, Department of Physical Rehabilitation, Ergotherapy within Physical Education Course,

Ivano-Frankivsk, Ukraine,

ORCID ID: 0000-0003-2584-3330,

e-mail:tudosyv@gmail.com

Abstract. Parkinson's disease was discovered and described more than 250 years ago by J. Parkinson. It is the most common chronic disease affecting mostly elderly people (over 60 years of age) and in most cases men. Initially, James Parkinson described the disease as shaking palsy, due to the main symptom of the condition. Risk factors for Parkinson's disease include: age, genetics, gender and exposure to toxins.

At the heart of the disease lies the progressive destruction of neurons that produces the neurotransmitter dopamine in the black substance. With the course of time, this leads to insufficient production of dopamine, and when its amount is reduced to $70 \%$ - motor and nonmotor manifestations of the disease are observed. Parkinson's disease can be recognized by the following symptoms: muscle rigidity, tremor, slowness of movement, hypokinesia, postural disorders, autonomic, cognitive and psychological disorders, problems with speech and swallowing. The quality of movements in patients depends on their environment, care provided at home and medical treatment prescribed.

Hoehn and Yahr described five stages of the disease; three types of progression mark the transition from one stage to another. This scale, introduced in 1967, is known as Unified Parkinson's Disease Rating Scale. The 3 types of progression are differentiated depending on the stage of Parkinson's disease - a fast progression, a mild progression and a slow one. Nearly every author admits usefulness of applying different rehabilitation measures and drug treatments to combat minor symptom complexes, which appear due to forced akinetic lifestyle, muscle contractures, various deforming arthritis or pain syndromes.

Regular rehabilitation can slow down the progression of symptoms. The purpose of physical therapy is to prevent or reduce the rate of symptoms progression and to promote adaptation of patients to existing motor disorders. The task of physical therapists is to find the optimal strategy to train performing those movements that are difficult, to encourage the independence of people. Individual program for each patient should be developed to address the existing problems of a specific person. Each session should be focused on training those muscle groups and movements that will help overcome the existing movement disorders caused by the disease. The body massage has a positive effect; it also promotes normalization of CNS functions, and restores muscular mobility. The therapists apply combined methods of manual classical massage and trigger point massage. The preferred types of massage technique are long gliding strokes, kneading, and rhythmical strokes to an area being worked on in order to stimulate nerves, muscles, and circulation. The purpose of occupational therapy is to ensure the independence of the patients in daily activities from outside help, to equip their environment with comfortable and safe things, where everything is in close proximity.

Due to biological reaction, the patients develop the ability to control the position of center of gravity, which helps them to move without loss of balance. It is advisable to introduce physiotherapy into treatment: hydrotherapy (fresh, sodium chloride, iodine-bromine, sulfur baths, oxygen hydrotherapy) and electroconvulsive therapy.

Keywords: Parkinson's disease, physical therapy, ergotherapy, biological reaction. 